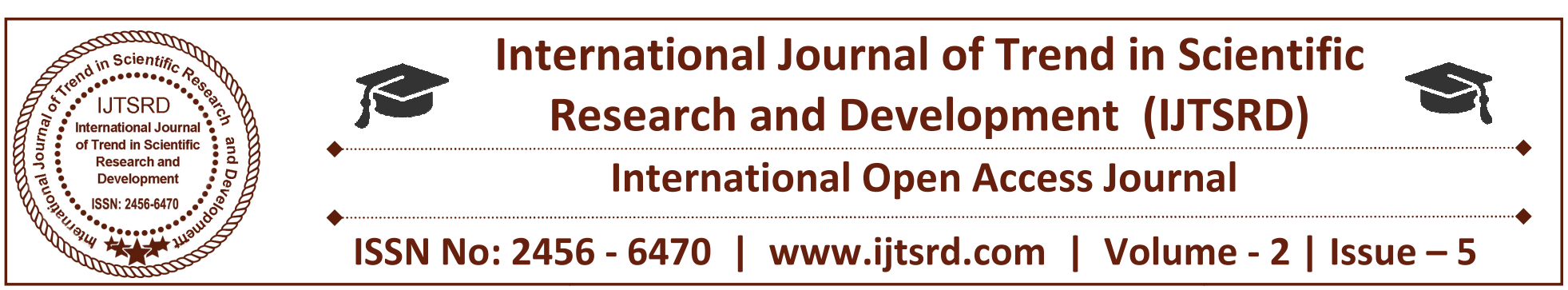

\title{
Mixed Nodular Liver Cirrhosis:A Case Report
}

\author{
Dr. Jyoti Umarji ${ }^{1}$, Dr. Shobha $G^{2}$, Dr. Vislavath Srikanth ${ }^{1}$ \\ ${ }^{1}$ Post Graduate Scholar, ${ }^{2}$ Assistant Professor \\ Department of Rachana Sharir, Sri Dharmasthala Manjunatheshwara College of Ayurveda and Hospital, \\ Hassan, Karnataka, India
}

\begin{abstract}
Cirrhosis of the liver is a diffuse disease, involves entire liver. The prevalence of Cirrhosis increasing globally. Every year approximately 10 lack patients are newly diagnosed in India. The common causes are Chronic Hepatitis C and Alcohol-related liver disease. Patients with compensated cirrhosis may present with non-specific symptoms or may be asymptomatic. It is associated with the several complications, which have serious effect on health and prognosis of the disease. The end-stage of cirrhosis is irreversible and liver transplantation is the only definitive management. This is a case of liver cirrhosis observed in a 70 years old male cadaver during routine dissection in the department of Anatomy. It highlights about a mixed nodular cirrhosis of liver. The Knowledge of liver cirrhosis is important for General physicians, Radiologist and Surgeons.
\end{abstract}

Keywords: Liver, Cirrhosis, Mixed nodular cirrhosis, Alcoholic liver disease

\section{INTRODUCTION}

Liver is a wedge shaped, largest organ in the body and is essential for metabolism, digestion, synthesis of proteins, detoxification and storage of glucose. It is located in right upper quadrant of the abdominal cavity. It is vulnerable to a wide variety of metabolic, toxic, microbial, circulatory and neoplastic injuries. Liver diseases such as Alcoholic, Non-alcoholic fatty liver diseases and Hepatitis A, B, C damages the normal hepatocytes and impairs its function. ${ }^{[1]}$ Liver cirrhosis is a diffuse disease, involves entire liver with disorganised normal lobular architecture. Liver can regenerate most of its own cells when damaged. The chronic injury to liver cells produces incomplete regeneration and forms nodules. These nodules are separated individually by fibrous bands and produce scaring of liver. The size of nodules was often varying from micro to macro depending on underlying cause. This type of mixed nodular cirrhosis is often seen in alcoholic liver disease. ${ }^{[2]}$ The prevalence of cirrhosis is increasing worldwide. According to WHO reports, cirrhosis of liver is the $10^{\text {th }}$ most common cause of death in India. ${ }^{[3]}$ It has many causes; the common cause is Chronic Hepatitis $\mathrm{C}$ and Alcohol-related liver disease. Portal hypertension is a common complication in liver cirrhosis. ${ }^{[4]}$ In advanced stages it is irreversible, but early diagnosis allows a chance for complete recovery. Liver transplantation is the only definitive treatment for end-stage of cirrhosis. ${ }^{[5]}$ The present case describes the mixed nodular cirrhosis of liver in a male cadaver found during routine dissection.

\section{CASE REPORT}

This is a case of liver cirrhosis observed in a 70 years old male cadaver during routine dissection for undergraduate students in the department of Anatomy at SDM college of Ayurveda and Hospital, Hassan. The Cadaver belongs to south India, Karnataka region obtain through voluntary body donation programme and was formalin fixed for routine dissection for teaching. While doing dissection of abdomen after removing peritoneum, noted mixed nodular growths on the surface of liver and photographs were taken. The normal architecture of the liver parenchyma has been destroyed by this nodular formation. The size of nodules was varying from $1 \mathrm{~mm}$ to $5 \mathrm{~mm}$. 
Photographs showing Mixed nodular cirrhosis of liver.

Figure 1:

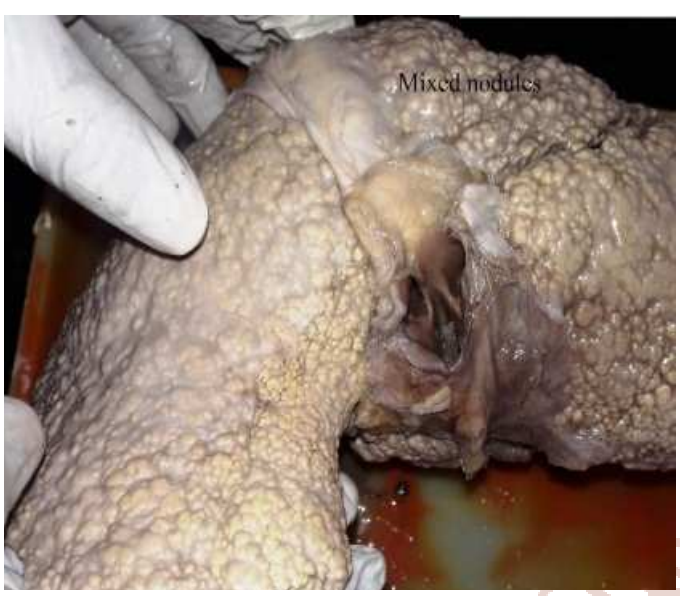

(a) Superiorsurface

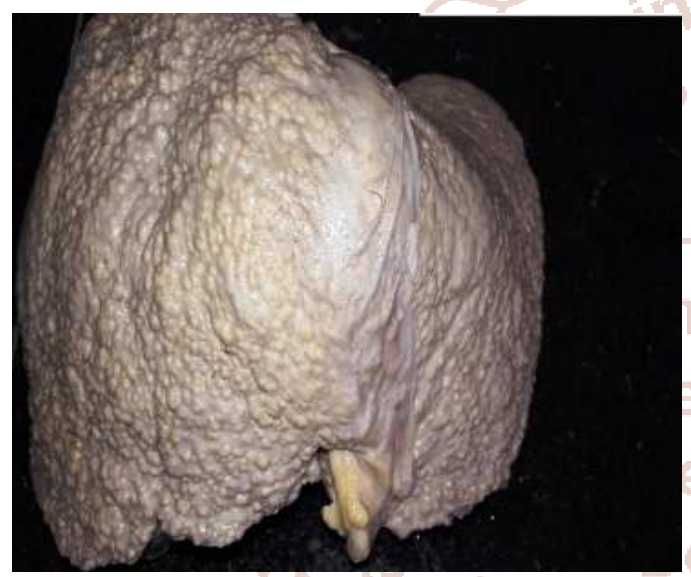

(b) Anterior surface

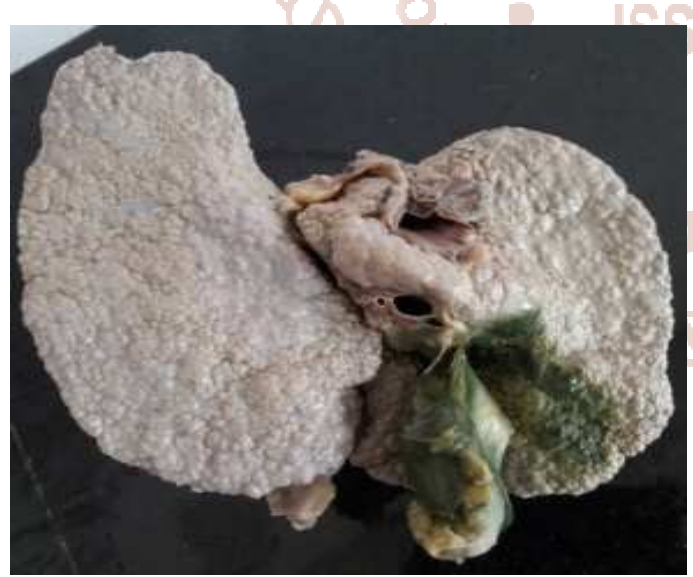

(c) Posteriorsurface

\section{DISCUSSION}

Liver is the largest internal organ in human body, which is responsible for synthesis of all circulating proteins. ${ }^{[6]}$ It is vulnerable to a wide variety of metabolic, toxic, microbial, circulatory and neoplastic injuries. Cirrhosis of the liver is a diffuse disease, defined as the histological development of regenerative nodules surrounded by fibrous bands in response to chronic liver injury. ${ }^{[7]}$ It is difficult to estimate the prevalence because many people with cirrhosis have no symptoms in the early stages of the disease. ${ }^{[8]}$ The global prevalence of cirrhosis from autopsy studies ranges from $4.5 \%$ to $9.5 \%$ of the general population. Hence it is estimated that more than 50million people in the world would be affected. [9] According to WHO reports, liver disease deaths in India is $2.95 \%$, and death rate is 22.93 per 100,000 of general population. Around 10 lacks patients of liver cirrhosis are newly diagnosed every year in India. ${ }^{[10]}$ The incidence of cirrhosis is more common in men than in women. ${ }^{[11]}$ Cirrhosis has many possible causes; sometimes more than one cause is present in the same person. Globally, 57\% of cirrhosis is attributable to either hepatitis B (30\%) or hepatitis C (27\%). Alcohol consumption is another major cause, accounting for about $20 \%$ of the cases. ${ }^{[12]}$ These causative factors divided into three groups: hepatocellular, cholestatic, and hepatic venous outflow obstruction. ${ }^{[13]}$

Table. 1 : Classification of cirrhosis according to

\begin{tabular}{|c|c|c|}
\hline Hepatocellular & Cholestatic & $\begin{array}{c}\text { Venous } \\
\text { outflow } \\
\text { obstruction }\end{array}$ \\
\hline $\begin{array}{c}\text { Viral } \\
\text { hepatitis(B, C, } \\
\text { D) }\end{array}$ & $\begin{array}{c}\text { Biliary } \\
\text { obstruction }\end{array}$ & $\begin{array}{c}\text { Veno- } \\
\text { occlusion } \\
\text { disease }\end{array}$ \\
\hline 6-6 Alcohol & $\begin{array}{c}\text { Primary biliary } \\
\text { cirrhosis }\end{array}$ & $\begin{array}{c}\text { Budd - } \\
\text { Chiari } \\
\text { syndrome }\end{array}$ \\
\hline Autoimmune & $\begin{array}{c}\text { Primarysclerosing } \\
\text { cholangitis }\end{array}$ & $\begin{array}{c}\text { Congestive } \\
\text { heart failure }\end{array}$ \\
\hline Metabolic & Drugs /toxins & $\begin{array}{c}\text { Constrictive } \\
\text { pericarditis }\end{array}$ \\
\hline Steatohepatitis & \multicolumn{2}{|c|}{$\begin{array}{c}\text { Drugs } \\
\text { /toxins }\end{array}$} \\
\hline \multicolumn{2}{|c|}{ Drugs /toxins* } & \multicolumn{2}{|c|}{ *Drugs and toxins can cause all 3 forms of liver } \\
disease.
\end{tabular}

Irrespective of aetiology, Cirrhosis is initiated by hepatocellular necrosis. Continued destruction of hepatocytes causes collapse of normal lobular hepatic parenchyma followed by fibrosis around necrotic liver cells. That causes formation of compensatory regenerative nodules separated by individual fibrous bands. Morphologically, Cirrhosis divided on the basis of nodule size. The Micro nodular cirrhosis contains regular and small nodules with less than 
$3 \mathrm{~mm}$ in diameter, often caused by alcoholic liver or biliary tract disease. The Macro-nodular is characterized by large irregular nodules with broad bands of connective tissue, most commonly occurs in viral hepatitis. Due to cessation of alcohol use, the larger nodules may form resulting in mixed nodular cirrhosis. ${ }^{[14]}$

\section{CLINICAL FEATURES}

The range of clinical features in cirrhosis varies widely, from an asymptomatic state to progressive liver failure and death. The general symptoms of compensated cirrhosis are weakness, fatigue, musclecramps, weight loss and other non-specific digestive symptoms. When decomposition develops, patient may present with symptoms due to hepatic insufficiency and portal hypertension. These symptoms are summarized in table no:2. ${ }^{[15}$

Table. 2 : Clinical features of hepatic cirrhosis

\begin{tabular}{|c|c|c|}
\hline $\begin{array}{l}\text { S. } \\
\text { No }\end{array}$ & $\begin{array}{l}\text { Clinical } \\
\text { features }\end{array}$ & \\
\hline 1 & Hepatomegal & $\begin{array}{l}\text { Swelling over right side } \\
\text { of the abdomen }\end{array}$ \\
\hline 2 & Jaundice & Icterus, itching \\
\hline 3 & Ascites & Distension of abdomen \\
\hline 4 & $\begin{array}{c}\text { Circulatory } \\
\text { changes }\end{array}$ & $\begin{array}{l}\text { Spider telangiectasia, } \\
\text { palmar erythemia, } \\
\text { cyanosis }\end{array}$ \\
\hline 5 & $\begin{array}{l}\text { Endocrine } \\
\text { changes }\end{array}$ & $\begin{array}{c}\text { Loss of libido, hair loss } \\
\text { Men:Testicular atrophy, } \\
\text { impotence } \\
\text { Women:Amenorrhea, } \\
\text { breast atrophy }\end{array}$ \\
\hline 6 & $\begin{array}{l}\text { Haemorrhagic } \\
\text { tendency }\end{array}$ & Bruise, purpura, epistaxis \\
\hline 7 & $\begin{array}{c}\text { Portal } \\
\text { hypertension }\end{array}$ & $\begin{array}{l}\text { Splenomegaly, collateral } \\
\text { vessels, variceal bleeding }\end{array}$ \\
\hline 8 & $\begin{array}{c}\text { Hepatic } \\
\text { encephalopathy }\end{array}$ & - \\
\hline 9 & Other features & $\begin{array}{l}\text { Pigmentation, digital } \\
\text { clubbing, low grade fever }\end{array}$ \\
\hline
\end{tabular}

Several classifications have been proposed to estimate severity of liver damage, which includes Morphological, Histological, Etiological and Clinical features. The most useful classification incorporates the latter two categories (table03). ${ }^{[16]}$
Table. 3 : Classification of liver cirrhosis.

\begin{tabular}{|c|c|c|}
\hline S. & TYPES & SUB-TYPES \\
\hline 1 & Morphological & $\begin{array}{c}\text { Macro nodular, micro } \\
\text { nodular, mixed nodular } \\
\text { cirrhosis. }\end{array}$ \\
\hline 2 & Histologic & Post hepatic, Post necrotic \\
\hline 3 & Etiological & $\begin{array}{c}\text { Viral, Alcoholic-related } \\
\text { liver cirrhosis }\end{array}$ \\
\hline 4 & Clinical & $\begin{array}{c}\text { Compensated, } \\
\text { Decompensated cirrhosis. }\end{array}$ \\
\hline
\end{tabular}

\section{DIAGNOSIS}

Cirrhosis of liver is diagnosed on the basis of symptoms, Physical examination, Medical history, laboratory tests and radiological findings. Laboratory tests are performed to determine the presence and severity of the liver disease and to establish the aetiology. ${ }^{[17]}$ Aspartate aminotransferase, Alanine transaminase, Alkaline phosphatase, bilirubin, prothrombin time, Gamma-glutamyl transpeptidase, Albumin, immune-globulins mainly IgG, Creatinine level, sodium level, Low sodium indicates severe liver disease. UA a predominant increase in serum aminotransferases (ALT and AST) suggests hepatocellular disease, while a predominant increase in alkaline phosphatase indicates biliary tract abnormality. In hepatitis B virus (HBV) and hepatitis $\mathrm{C}$ virus (HCV) infections, ALT is greater than AST; while in alcoholic liver disease, AST is greater than ALT. Abnormalities of serum albumin and prothrombin time indicate severity of disease and poor prognosis. ${ }^{[18]}$ Ultrasonography provides important information on hepatic architecture, changes in Liver volume, size and oftena nodular deformation of the liver. Endoscopy and Doppler imaging are the most useful tools in diagnosis and management of portal hypertension and its complication. The nodular lesions should be confirmed by helical CT or MRI. Computed Tomography (CT) scan shows hepatosplenomegaly and dilated collaterals with good intensity. Magnetic Resonance Imaging (MRI) has shown effective in diagnosis of benign tumours, vascular anatomy, biliary tree and hepatic iron and fat content in hemochromatosis. ${ }^{[19]}$ The scaring of liver can estimate with some reliability by Elastography. Liver biopsy considered as gold standard for diagnosis and sequential histological grading of fibrosis. ${ }^{[20]}$ 


\section{MANAGEMENT}

There is no treatment that will arrest or reverse the cirrhotic changes, but progression can be halted by preventing underlying cause. In early stages of Cirrhosis symptomatic relief and avoiding causative factor is helpful. Poor nutrition is one the cause for progression of the disease. In absence of encephalopathy and Ascites, a high protein rich diet is provided. ${ }^{[21]}$ Portal hypertension is a major complication of cirrhosis. It causes gastro esophageal varices with haemorrhage, Ascites and hypersplenism. Acute variceal bleeding treated with combined endoscopic and drug therapy. The trans-jugular intrahepatic portosystemic shunt procedure is used in continue bleeding cases. Ascites can manage by using Salt restriction diet, Diuretics and Paracentesis. Liver transplantation is the definitive management in hepatorenal syndrome and hepatic encephalopathy. ${ }^{[22]}$ Cirrhosis is the major risk factor for progression to Hepatocellular carcinoma. It is managed with multiple treatment modalities that depend on tumour size, number of tumourand local expertise. ${ }^{[23]}$ If complications cannot be controlled or when the liver ceases functioning, liver transplantation is necessary. [24]

\section{CONCLUSION}

Prevalence of liver cirrhosis is very common with history of chronic hepatitis $\mathrm{C}$ and alcohol-related liver disease. This case is presented with mixed nodules, may be due to cessation of alcohol use, where large nodules may form resulting in mixed nodules. So, this case was may be developed from alcoholic liver diseases. Clinically it was compensated cirrhosis because complications such as ascites, portal hypertension features not seen. The Knowledge of liver cirrhosis is important for General practitioners, Radiologist and Hepato-biliary surgeons.

\section{REFERENCE}

1. DanLongo et al, Harrison's principles of internal medicine, 18thed, New York: McGraw-Hill Education Medical; 2012, p2592.

2. Mohan H, Text Book of Pathology, 4thed, New Delhi: Jaypee Brothers medical publishers (pvt) Limited; 2010, p600-601

3. WHO- global health observatory data respository2014

4. DanLongo et al, Harrison's principles of internal medicine, 18thed, New York: McGraw-Hill Education Medical; 2012, p 2592.
5. Anand B S, Cirrhosis of liver, West J Med; 1999 Aug, 171(2): 110-115.

6. Kumar P, Clark M. Kumar \& Clark's Clinical Medicine, 7thed, Edinburgh: Saunders/Elsevier; 2009, p287-289

7. Mohan H, Text Book of Pathology, 4thed, New Delhi: Jaypee Brothers medical publishers (pvt) Limited; 2010, p600.

8. The National Digestive Diseases Information Clearinghouse (NDDIC), Cirrhosis of the Liver Information Sheet Ver3. 0 - July 2013, p 1-07 (www. digestive. niddk. nih. gov).

9. WHO-global health observatory data respository2014.

10. Anderson R N, Smith B L, "Deaths: leading causes for 2001", National Vital Statistics Reports, canters for Disease Control and Prevention; 2013, 52 (9): 1-85.

11. Perz J F, Armstrong G L, Farrington L A, Hutin Y $\mathrm{J}$, Bell B P, The contributions of hepatitis B virus and hepatitis $C$ virus infections to cirrhosis and primary liver cancer worldwide, J. Hepatol;2006, 45 (4): 529

12. DanLongo et al, Harrison's principles of internal medicine, 18th ed, New York: McGraw-Hill Education Medical; 2012, p 2594.

13. Anand B S, Cirrhosis of liver, West J Med; 1999 Aug, 171(2): 110-115.

14. Mohan H, Text Book of Pathology, 4th ed, New Delhi: Jaypee Brothers medical publishers (pvt) limited;2010, p 600.

15. Edwards C R W, et al. Davidson's principles and practice of medicine, 17thed, Edinburgh; New York: Churchill Livingstone; 1995, p 524-525.

16. Anand B S, Cirrhosis of liver, West J Med; 1999 Aug, 171(2): 110-115.

17. The National Digestive Diseases Information Clearinghouse (NDDIC), Cirrhosis of the Liver Information Sheet Ver3. 0 - July 2013, p 1-07 (www. digestive. niddk. nih. gov).

18. Godakar B P, Godakar P D, Textbook of medical laboratory technology, 2nded, New Delhi: Bhalani publishing house;2011, p339-344.

19. Suval M A, A Brief Review on Liver Cirrhosis: Epidemiology, Etiology, Pathophysiology, Symptoms, Diagnosis and Its Management, 
Inventi Rapid: Molecular Pharmacology; Vol. Corresponding author: 2014, Issue2.

20. Schuppan D, Amdahl NH, Liver Cirrhosis, Lancet; 2008 March 8, 371(9615): 838-851.

21. Kumar P, Clark M. Kumar \& Clark's Clinical Medicine, 7thed, Edinburgh: Saunders/Elsevier; 2009, p316.

22. DanLongo et al, Harrison's principles of internal medicine, 18thed, New York: McGraw-Hill Education Medical; 2012, p 2597-2602.

23. Schuppan D, Afdhal NH, Liver Cirrhosis, Lancet; 2008 March 8, 371(9615): 838-851.

24. Masterton G S, Hayes P C, Coffee and the liver: a potential treatment for liver disease?, Eur J Gastroenterol Hepatol; 2010, 22 (11): 1277
1. Dr Jyoti Umarji, Post Graduate Scholar, Sri Dharmasthala Manjunatheshwara College of Ayurveda and Hospital, Hassan, Karnataka, India M. No.9611901695, E-mail:drjsumarji04@gmail.com

2. Dr Shobha G, Assistant professor, Sri Dharmasthala Manjunatheshwara College of Ayurveda and Hospital, Hassan, Karnataka, India M. No. 9844827656 ,

E-mail: drshobhagirish@gmail.com

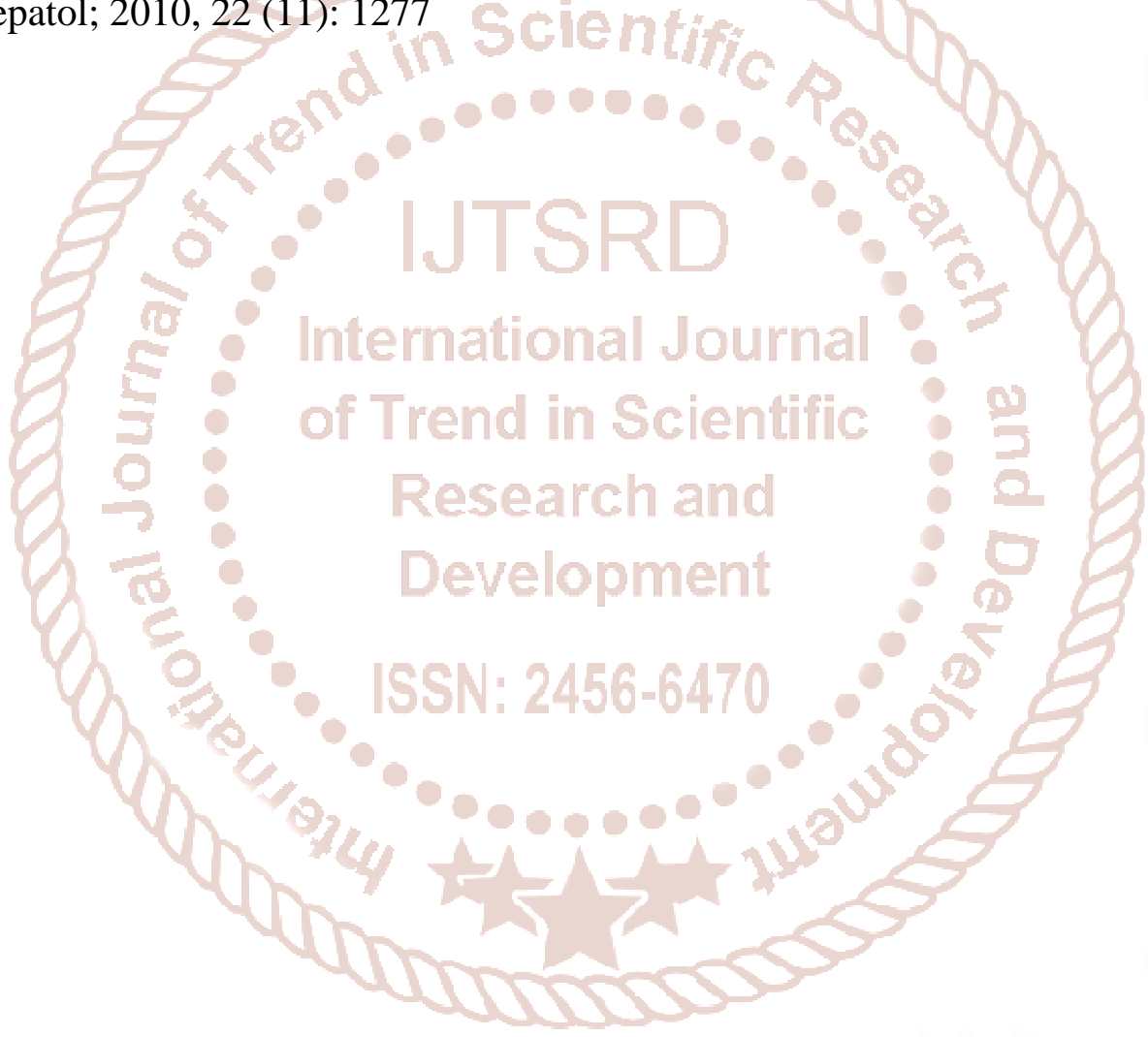

